\title{
Augmented Reality and Museum Exhibition. The Case of the Tribuna of Palazzo Grimani in Venice
}

Giuseppe D'Acunto

\section{Abstract}

The purpose of this research was the exploration of the potential of the combined use of augmented reality and rapid propotyping for the enhancement of Cultural Property. This specific study explored how these innovative methodologies can be effective in the creation of museum exhibitions which are not only able to show the contents of the exhibition itself in an original and captivating way, but also to recover the memory of a place by reconstructing the original position of the surroundings strictly connected to the sculptures they have been deprived of over the centuries.

It is the case of the Tribuna of Palazzo Grimani in Venice and of the statues that used to adorn its walls. The majority of these statues are now preserved in the National Archaeological Museum of Venice in an attempt to reconstruct their original appearance and disposition, and to offer the public a wholesome vision through augmented reality.

\section{Keywords}

augmented reality, digital models, digital survey, museum exhibitions.

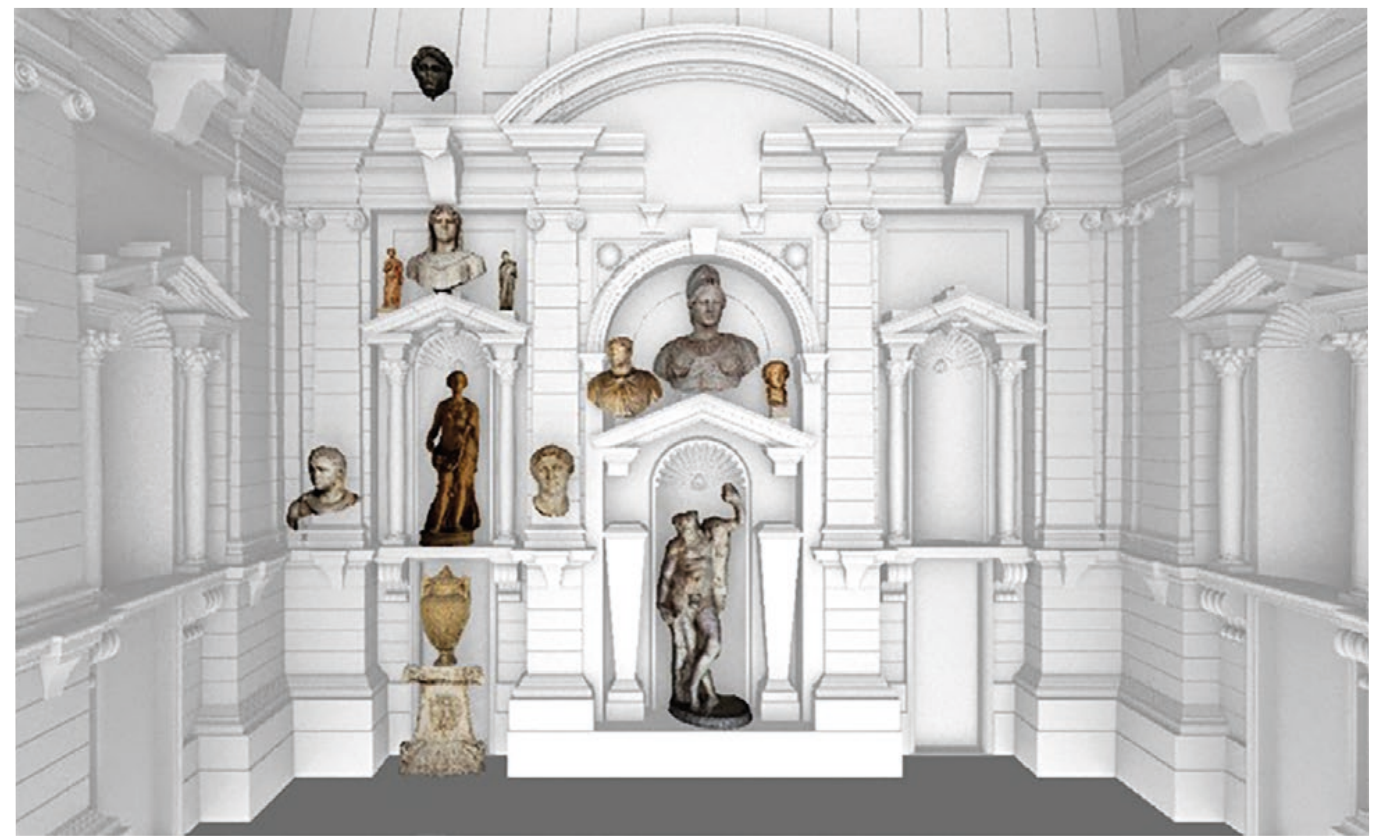


Fig. I. (left)

onstruction of a

portion of the Tribuna by Federico Zuccari, I 582. British Museum, London (right) Reconstruction of the wall facing the entrance. Favaretto I., De Paoli M. 2010
Among the various challenges that those who deal with exhibitions have to face every day, one of the most stimulating and insidious at the same time is the representation of the intangible value of the exhibited goods. Representing the intangible stratification of meanings and contents of a fragment of heritage - it being archaeological, architectural, cultural, or of any other nature - is an undertaking not to be taken for granted and is characterised by the need to maintain a continuous equilibrium between scientific rigor and narrative effectiveness. From this point of view, the evolution of the narrative codes and the increasingly widespread and rooted presence of the media have played a fundamental role in, on one hand, enormously enriching the range of solutions available to designers and curators, and, on the other hand, making this field significantly more complicated. Therefore, it is not surprising that, with usable patterns increasingly more shaped by the indissoluble influence of technology and its complicated rules - immediacy, accessibility, superabundance, experientiality - the contamination of the traditional codes with innovative languages and other narrative solutions has become a trend that is as natural as unavoidable and necessary. This is even more evident when museums are concerned, since the quality of an exhibition is determined, among other factors, also by the ability to show the intangible value of the exhibited goods in a tangible, effective and, most importantly, universal way.

The reconstruction of the position of the statues of the Tribuna of Palazzo Grimani in Venice exegetically explained in this essay is an experimentation of a museum exhibition in one of the most iconic places of Venice structured and organised according to the possibilities offered by augmented reality. The purpose is to show the original aspect of this place that has been lost over time.

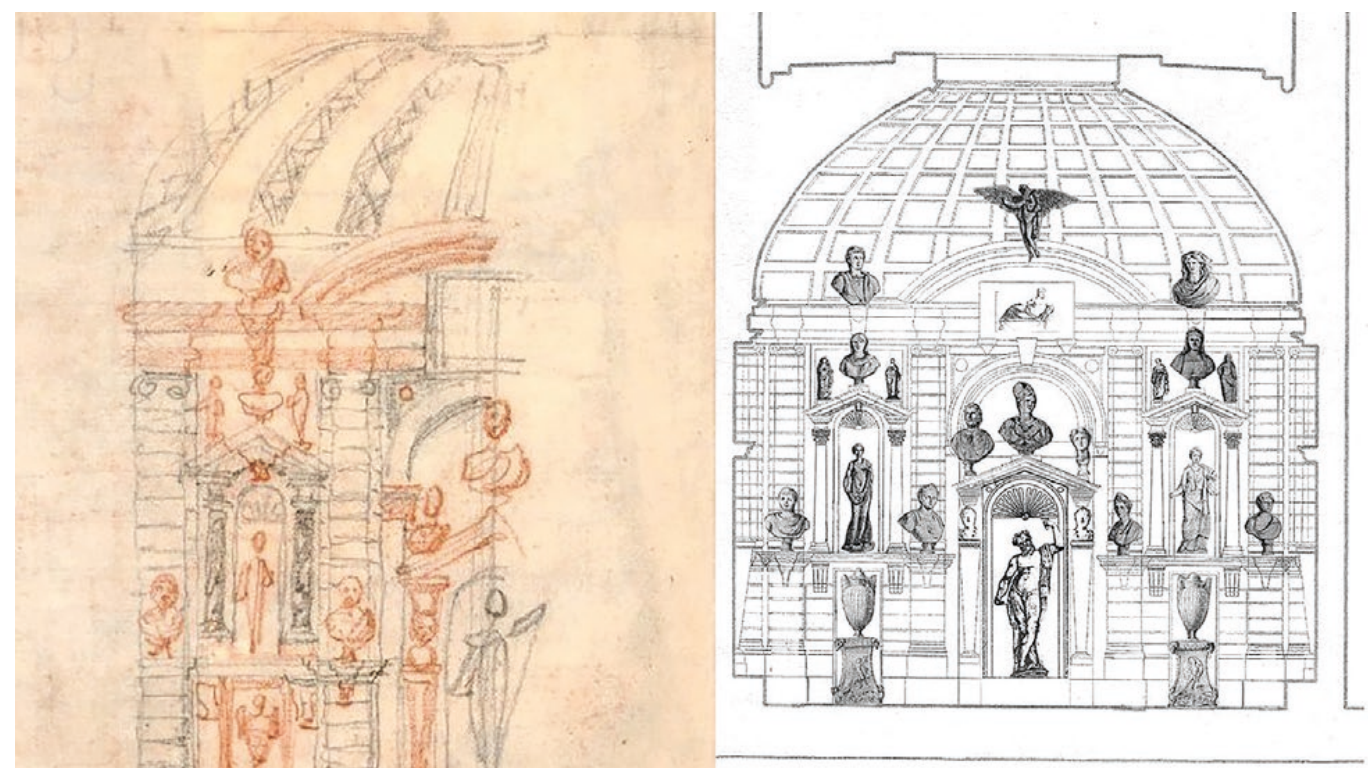

The Tribuna was built in the second half of the 16th century at the will of Giovanni Grimani, patriarch of Aquileia. It was clearly inspired by the Pantheon and illuminated from the above by an opening in the centre of the roof vault. It contained an entire collection of statues in a very scenographic way due to an articulated system of lights and a refined system of niches and shelves. Even though there is no written evidence, it seems that the critics have endorsed the theory according to which Francesco Sansovino curated the architectural project of the Tribuna, as reported for the first time in a small anonymous guide of the end of the 18th century called Pitture e scolture nel palazzo di casa Grimani a Santa Maria Formosa. This space was attributed the name 'Tribuna' only in the descriptions of the guides between the 18th and 19th centuries [1], but it was originally known as Antiquarium (studio of antiquities), as reported by Francesco Sansovino in his famous book 'Venetia città nobilissima et singolare' dated I58I [2]. In another passage of this book, there is a detailed narration of the 
visit of Henry III, king of France, and Alfonso II, duke of Ferrara, to patriarch Grimani in the autumn of 1574. Sansovino described the amazement of the two illustrious guests towards the wonders that the Venetian Palace and, in particular, the Tribuna - where the entire collection of statues was displayed - offered.

Thus, it can be assumed that the Tribuna was largerly complete between the 60s and 70s of the 16th century, and the fame of its wonders had already spread throughout Europe, even though this setting, as originally organised, survived only less than thirty years. While still alive, Grimani bequeathed the entire collection of statues to the Serenissima Republic of Venice in I586, with the intention to create a Public Statuary situated in the anteroom of the Marciana Library. According to the chronicles of the time, the transfer of the statues to the Statuary of the Serenissima started in 1593 (the same year in which Grimani died) and ended in 1596. During this operation, the first inventory of the entire collection, known as the Pellegrini Inventory [3], was compiled. This document is still of great importance in the attempt to recreate the historical issues of the Tribuna and it is one of the few written descriptions of the entire collection of statues in the room before their transfer to the Public Statuary. Another fundamental document that gives us the precise idea of the original aspect of the Tribuna in those years is the description dated 1593 that can be found in 'Storia del Friuli' by Germano de'Vecchi.

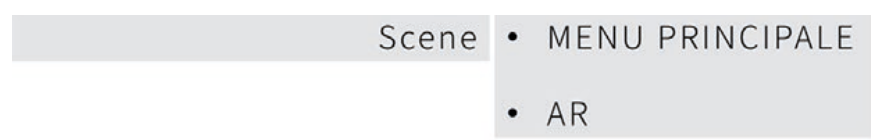

Target PAVIMENTO
Fig. 2. The screen of the application in augmented reality with an example of multimedia card with the in-depth interactive contents for each individual statue. Digita elaboration by Valeria Sambucini.
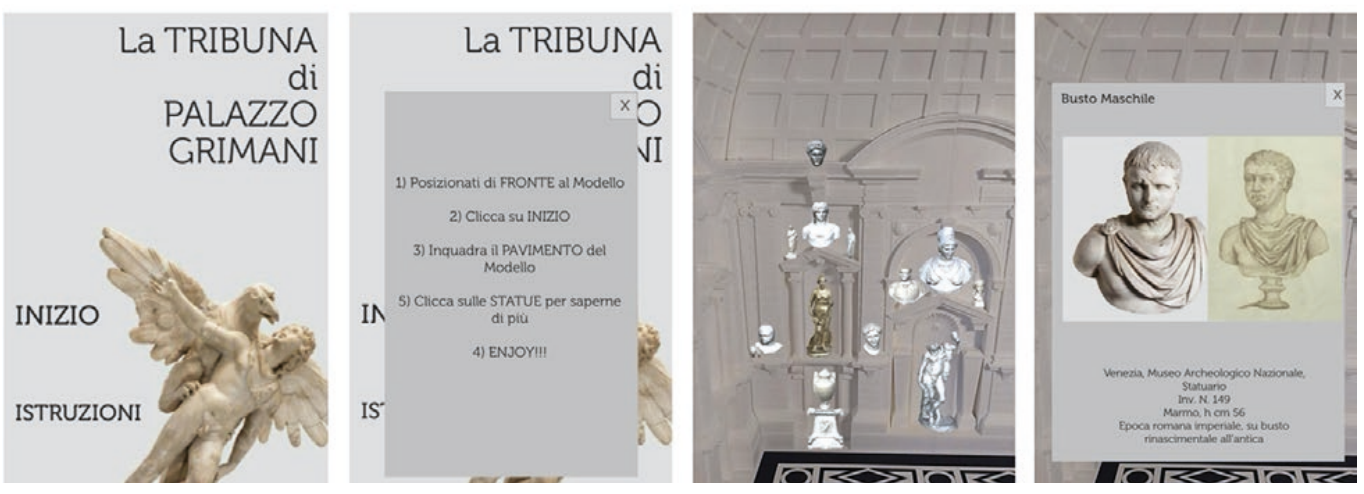

As already mentioned before, the descriptions and positions of each statue as reported in the two inventories are incomplete and often approximate and they lack a graphic apparatus able to convey the exhibition in its original aspect with the correspondent disposition of the sculptures in the Tribuna.

Among the various studies about the Tribuna of Palazzo Grimani and its collection of statues, one that is worth to remember is that of the scholar Marilyn Perry [4] who, in 1972, was able to reconstruct the current disposition of the statues as reported in the inventories of Pellegrini and de'Vecchi inside the Archaeological Museum of Venice using also the drawings made by Anton Maria Zanetti 'the Young' in 1736. This contribution is a fundamental stage in the attempt to virtually reconstruct the original exhibition of the Tribuna. Unfortunately, Perry's study did not manage to reconstruct the exact disposition of the statues. A first and plausible hypothesis, then widely supported by critics, can be found instead in the study of the scholar Eva Soccal [5]. In her graduation thesis of 1999, Soccal hypothesised that the inventory of Pellegrini followed a circular trend in the enumeration of the statues, starting from the sculptures situated at the base of the walls and then rising helically upwards. The idea suggested by Soccal became an installation in an exhibition that took place in Bonn 
in 2002 and that was dedicated to collectors and Venetian art. The images of the walls of the Tribuna were printed in a I:I scale and used as background for some of the original sculptures lent by the Archaeological Museum of Venice. Drawings by Zanetti were instead used as background for the sculptures that were supposedly originally placed in niches and on upper shelves.

It is probably superfluous to point out that this research [6], mainly focused on the digital reconstruction of the Tribuna, had to rely upon reconstructions made by art historians and archaeologists who have received great credit from the scientific community.

Apart from the already mentioned Soccal's study, the other most important research is ' $\mathrm{a} a$ Tribuna ritrovata. Uno schizzo inedito di Federico Zuccari con l'Antiquario dell'illustrissimo Patriarca Grimani' by Irene Favaretto and Marcella de Paoli. The work of the two Venetian scholars has been inspired by the finding of a drawing that apparently has nothing to do with the Tribuna of Palazzo Grimani.This drawing by Federico Zuccari is a reproduction of 'The Feast in the House of Simon the Pharisee' made by Paolo Veronese in I 573 [7] and is preserved in the Department of Prints and Drawings of the British Museum in London. On the back of this drawing there is a freehand sketch made by the author himself which represents an image, although partial, of the Tribuna of Palazzo Grimani when it was full of Greek and Roman statues. The sketch represents the right half of the wall facing the entrance of the Tribuna. Although the drawing is incomplete, Favaretto and de Paoli have tried to reconstruct, even though only on paper, the entire room, hypothesising its organisation in the 80s of the 16th century with the repositioning of about 100 statues. (fig. I)

Discussing the specifics of the digital reconstruction, after an intense study of the sources with the collaboration of art historians and archaeologists, the first operation carried out was a laser scan survey of the space of the Tribuna and the creation of a physical 3D model. Moreover, once the statues were positioned in their current location, some of them were surveyed using digital photogrammetry, in particular the Hora d'Autunno, which is nowadays preserved in the antitribune hall of Palazzo Grimani. They survey and modelling of all the statues was a long and complex work that involved only a few cases in this first phase, trying to build and explore a methodology that was then completed thanks to the collaboration with the Directorate of Cultural Activities and Sport of the Veneto Region, which lent the models of the missing statues. The data regarding the room and the statue obtained through the photogrammetrical survey were then processed through the software Agisoft Photoscan. The elaboration of the room was meant to obtain a three-dimensional model suitable to be then remodelled with a software of digital drawing in order to obtain a printable model. The elaboration of the statues was instead meant to obtain a texturised model that could be used to create the content of the application in augmented reality. The modelling made with the software Rhinoceros created a simplification of the digital clone of the room in terms of geometry and decorative details that are believed to be dated after I582 - the reference year of the hypothetical reconstruction. In particular, the floral decorations at the centre of the ceiling coffers of the vault, the plaster masks placed above the round arches of the main niches and the plaster survey that adorned the mirrors above the arches were removed. In addition, the entrance on the left wall and the window on the right wall were removed for the same reasons and they were replaced with niches.

To enable the view inside the room in the printed physical model, only one half of the room was printed - that is, the one resulting from the division of the room itself by means of a plane perpendicular to the floor and passing through the vertical axis of the left and the right walls. The half that was printed is the one that contains the wall facing the entrance of the Tribuna. The model was subsequently divided into independently printable sections that were then united among themselves with hooks (between the walls, and between the walls and the sections of the vault) made ad hoc or with a glue (between the sections of the vault, and these and the skylight). After the printing phase, an application in augmented reality was created using the Unity and Vuforia software. In particular, Unity is a software that enables to create a large number of applications such as apps for mobile devices, while Vuforia is a kit for the development of applications in augmented reality for mobile devices. The structure of the application includes a simple main menu that introduces the augmented reality 
scene and explains to the users how to use it through the 'instructions' command. That same application contains the interactive view of the original position of fourteen statues inside the Tribuna, that is, those relating to two thirds of the wall facing the entrance of the room. (fig. 2) The software Rhinoceros was initially used for the creation of the scene with the digital models of the statues to equalise the scale of the mesh models of the statues and that of the model of the room. Then, the models of the statues were virtually situated inside the Tribuna. Finally, the whole complex of the statues was exported in .obj format and imported into Unity to create the scene. Therefore, by framing the model of the Tribuna with a normal mobile device and thanks to some targets situated in the different support points of the statues, the image of the Tribuna with its statues appears. The next step consists of experimenting this application in the physical space of the Tribuna, considering the excellent functioning of the same on the scale model. The application designed in augmented reality offers interactive in-depth contents too: each statue has a multimedia card, consisting of a panel containing its real image, its representation made by Zanetti in his catalogue of 1736 , and a small text with its name, its current location, and some other information. This panel can be activated for each statue by clicking on the statue itself.

\section{Notes}

[I] Cf.: Moschini 1815 .

[2] Sansovino I58I, pp. |38-139.

[3] Cf.: Inventario Pellegrini, 16 november 1593 (asv, Procuratori de Supra, b. 68, proc. I 5 I, fasc. 3, I, cc. 33-42).

[4] Perry 1972, pp. 75-253.

[5] Soccal E. 1999-2000, La Tribuna di Palazzo Grimani. Ipotesi di ricostruzione di una raccolta d'antichità nella Venezia del XVI secolo, graduation thesis, University of Padua, supervisor Graduate I. Favaretto; Soccal 2002, pp. 447-455.

[6] Part of this work has been developed in the thesis Nuove Tecnologie per un Exhibit Museale Innovativo, Graduate Valeria Sambucini, for the II-level Master's degree Ml-Heritage Sistemi Interattivi e Digitali per la Restituzione e Valorizzazione del patrimonio Culturale of the luav University of Venice, scientific manager Prof. Giuseppe D'Acunto.

[7] For Federico Zuccari, see: Acidini Luchinat 1998 e Acidini Luchinat 200 I, pp. 235-240.

\section{References}

Acidini Luchinat Cristina (1998). Taddeo e Federico Zuccari Fratelli Pittori del Cinquecento. Milano-Roma: Jandi-Sapi.

Acidini Luchinat Cristina (200I). Federico Zuccari e Venezia. In Piantoni Mario, De Rossi Laura (eds.). Per l'arte da Venezia all'Europa. Studi in onore di Giuseppe Maria Pilo. Venezia: Edizioni della Laguna, pp. 235-240.

Favaretto Irene, De Paoli Marcella (2010). La Tribuna ritrovata. Uno schizzo inedito di Federico Zuccari con l'«Antiquario dell'Ill. Patriarca Grimani»s. In Eidola International Journal of Classic Art History, 7, pp. 97- 35.

Gallo Roberto (1952). Le donazioni alla Serenissima di Domenico e Giovanni Grimani. In Archivio Veneto, IXXXII, pp. $34-77$.

Moschini Giannantonio (I 8|5). Guida per la Città di Venezia. Venezia: Alvisopoli.

Perry Marylin (1972). The Statuario Publico of the Venetian Republic. In Saggi e Memorie di Storia dell'Arte, 8, pp. 75-253.

Sansovino Francesco (I58I).Venetia città nobilissima et singolare. In Venetia, pp. I38-I39.

Soccal Elena (2002). Sculture antiche a Venezia nel Cinquecento: Palazzo Grimani e il suo museo. La Tribuna nel XVI secolo. Proposte per una lettura del programma iconografico. In Colpo Isabella, Favaretto Irene, Ghedini Francesca (eds.). Iconografia 200 I. Studi sull'immagine, Atti del Convegno di Studi. Roma: Quasar edizioni, pp. 447-455.

\section{Author}

Giuseppe D'Acunto, Dept. of Architecture and Arts, luav University of Venice, dacunto@iuav.it 
